Article

\title{
Heavy Metal Accumulation and Anti-Oxidative Feedback as a Biomarker in Seagrass Cymodocea serrulata
}

\author{
Mohammed Othman Aljahdali $1, *($ i) and Abdullahi Bala Alhassan $1,2, *$ (i) \\ 1 Department of Biological Sciences, Faculty of Science, King Abdulaziz University, Jeddah 80203, \\ Saudi Arabia \\ 2 Department of Biology, Faculty of Life Sciences, Ahmadu Bello University, Zaria 810001, Nigeria \\ * Correspondence: moaljahdali@kau.edu.sa (M.O.A.); aalhassan0021@stu.kau.edu.sa (A.A.B.); \\ Tel.: +966-541046505
}

Received: 6 March 2020; Accepted: 30 March 2020; Published: 2 April 2020

check for updates

\begin{abstract}
The pursuit of a good candidate to biomonitor environmental pollutants has been on the increase. In this study, the concentrations of $\mathrm{Fe}, \mathrm{Mn}, \mathrm{Cu}, \mathrm{Zn}, \mathrm{Cd}, \mathrm{Cr}, \mathrm{Pb}$ and $\mathrm{Ni}$ in sediment, seawater and seagrass Cymodocea serrulata compartments and antioxidant enzymes activities in $C$. serrulata were determined. Our results revealed that bioconcentration factors for all the metals were less than 1 $(\mathrm{BCF}<1)$ and concentrations in seagrass compartments were in the order root $>$ leaf $>$ rhizome for Fe and $\mathrm{Mn}$, leaf $>$ root $>$ rhizome for $\mathrm{Cu}, \mathrm{Zn}, \mathrm{Pb}$ and $\mathrm{Ni}$, and root $>$ rhizome $>$ leaf for $\mathrm{Cd}$ and $\mathrm{Cr}$. Effect range low concentrations (ER-L) revealed that $\mathrm{Cu}, \mathrm{Zn}, \mathrm{Cd}, \mathrm{Pb}$ and $\mathrm{Ni}$ concentrations were above ER-L values and $\mathrm{Cr}$ concentration was below ER-L values while concentrations in seawater for all the heavy metals were above the estimate average element concentrations in seawater (ECS). Significant variation $(p<0.05)$ was recorded for heavy metals in sediment, seawater, seagrass compartments and heavy metal concentrations across stations. Influence of heavy metals on antioxidant enzymes activities; catalase (CAT), superoxide dismutase (SOD), glutathione S-transferase (GST) and acetylcholinesterase (AChE) were recorded, and high activities of the antioxidants were recorded in station $\mathrm{S} 8$ corresponding to high concentrations of heavy metals in the same station. There is a need for the promotion of biomonitoring networks across the marine environment using C. serrulata and antioxidant enzymes as biomarkers of oxidative stress caused by environmental pollutants.
\end{abstract}

Keywords: heavy metals; seagrass; accumulation; antioxidant enzymes; Rabigh; Cymodocea serrulata

\section{Introduction}

Heavy metal pollution in the marine ecosystem is on the increase worldwide and the concentrations of heavy metals in natural aquatic ecosystems in the last decade have reached dramatic levels $[1,2]$. Unlike organic pollutants, the persistent nature of heavy metals creates accumulation potential of these pollutants in sediments and moves up to different trophic levels in food webs with negative health effects on end-users of aquatic ecosystems resources, which are humans [3,4].

Heavy metals are one of the major pollutants of anthropogenic sources in the Red Sea, Saudi Arabia [5]. This is a result of pressures from humans such as dredging, reclamation, desalination and above all oil spills, as the region is one of the largest producers of crude oil worldwide [6]. The increase in heavy metal concentrations in the marine environment has led to the need for effective monitoring of the status of this environment as regards pollution by heavy metals. This provides opportunities for vital preservation of the marine ecosystem and conservation of other natural resources from the same environment $[7,8]$. 
The use of organisms such as seagrasses as biological indicators of marine pollution gives an advantage as to the provision of information on the spatial and temporal effects of pollutants such as heavy metals [9]. Organisms such as seagrasses with the potential to bioaccumulate heavy metals into their compartments are very important for use in the evaluation of pollutant loading in the environment and understanding the impacts of pollutants in the food web [10,11]. Seagrasses significantly contribute to the primary productivity in the marine ecosystem but are also employed in evaluating the concentration of heavy metals due to the principal uptake routes of heavy metals by these plants [11]. Features and characteristics such as the ability to bioaccumulate pollutants in high concentrations, importance in the food chain, abundance in an environment and widespread and easy identification made seagrasses suitable for use as good bioindicators [12]. The employment of seagrasses for assessment of heavy metals concentrations in components of the marine ecosystem is linked with the major routes of metal uptake as seawater/sediment to leaf/root pathways [13].

In organisms, when normal cellular activities are in progress, cell organelles such as chloroplast, mitochondria and peroxisomes as part of their function produce reactive oxygen species $\left(\mathrm{ROS} ; \mathrm{H}_{2} \mathrm{O}_{2}\right.$, $\left.\mathrm{O}_{2}{ }^{-}, \mathrm{OH}^{-}\right)[14,15]$. The production of ROS in cells may become high in conditions of stress that may be caused by pollution of an environment which affects the wellbeing of an organism. The excess production of ROS may cause oxidative damage/stress or cell damage by oxidation of nucleic acids, proteins, carbohydrates and lipids which are biological macromolecules $[2,4,16]$.

However, cells can respond to an increase in the production of ROS through a defence network of antioxidant enzymes with the capability of scavenging ROS produced [17,18]. This is the key reason why antioxidants are utilised as oxidative stress biomarkers that might have occurred as a result of an increase in ROS production, which has a positive correlation with increased pollutants in an environment $[11,19]$. The antioxidant enzymes frequently used are, but not limited to, catalase (CAT), superoxide dismutase (SOD), glutathione S-transferase (GST), acetylcholinesterase (AChE), peroxidase (POD) and malondialdehyde (MDA), among others $[16,17]$.

The focal objective of this study was to assess heavy metal accumulation and anti-oxidative feedback as biomarkers in seagrass Cymodocea serrulata. C. serrulata is the most abundant seagrass in the Rabigh lagoon, Red Sea, Saudi Arabia.

\section{Materials and Methods}

\subsection{Study Area and Sample Collection}

The study area for this study was Rabigh lagoon, Red Sea (Figure 1). The lagoon $\left(22^{\circ} 45^{\prime} \mathrm{N} 39^{\circ} 00^{\prime} \mathrm{E}\right.$, $23^{\circ} 00^{\prime} \mathrm{N} 38^{\circ} 45^{\prime} \mathrm{E}$ ) is situated northwest of Rabigh City, Kingdom of Saudi Arabia. Rabigh lagoon has a length on the average of $17 \mathrm{~km}$ with a width of $3 \mathrm{~km}$, and a depth ranging from 1 to $11 \mathrm{~m}$. At the northwestern part of the lagoon is its mouth where it is open to the Red Sea. The bottom of Rabigh lagoon possesses rich communities of seagrasses [5,11]. Very low tidal range $(20-30 \mathrm{~cm})$ is evident and the sediment texture in the lagoon ranges from mud and gravel sand to sandy mud [5].

The Sampling of $C$. serrulata was done putting into consideration the compartments (root, rhizome, and leaf) from the benthic region of the lagoon in eight stations selected based on factors like physical features, possible anthropogenic influence, the mouth of the lagoon, accessibility and abundance of seagrass. A T10 handheld GPS meter was used to read and record coordinates of the sampling stations and the stations labelled S1 to S8 (Figure 1).

The ranges of $10 \times 10 \mathrm{~m}$ to $30 \times 30 \mathrm{~m}$ of seagrass beds were considered for sampling and samples were collected randomly in an average area of $2000 \times 100 \mathrm{~m}$ for sampling in the study area. Coarse materials were removed from the sampled seagrasses, which were then rinsed with deionized water. The seagrass samples containing root, rhizome, and leaf were divided into two; one sample for heavy metal analysis and the second for antioxidant enzyme activity determination. The two samples were sealed in plastic zip-lock bags and placed in an icebox. At each station, benthic sediment $(0-20 \mathrm{~cm})$ and seawater were also collected into a zip-lock bag and amber coloured $1 \mathrm{~L}$ reagent bottles respectively. 
For the seawater samples, they were acidified by the addition of $1.6 \mathrm{~mL} \mathrm{~L}^{-1} \mathrm{HNO}_{3}$. All samples were placed in an icebox and moved to Ecophysiology Laboratory, Department of Biological Sciences, King Abdulaziz University for further analysis.

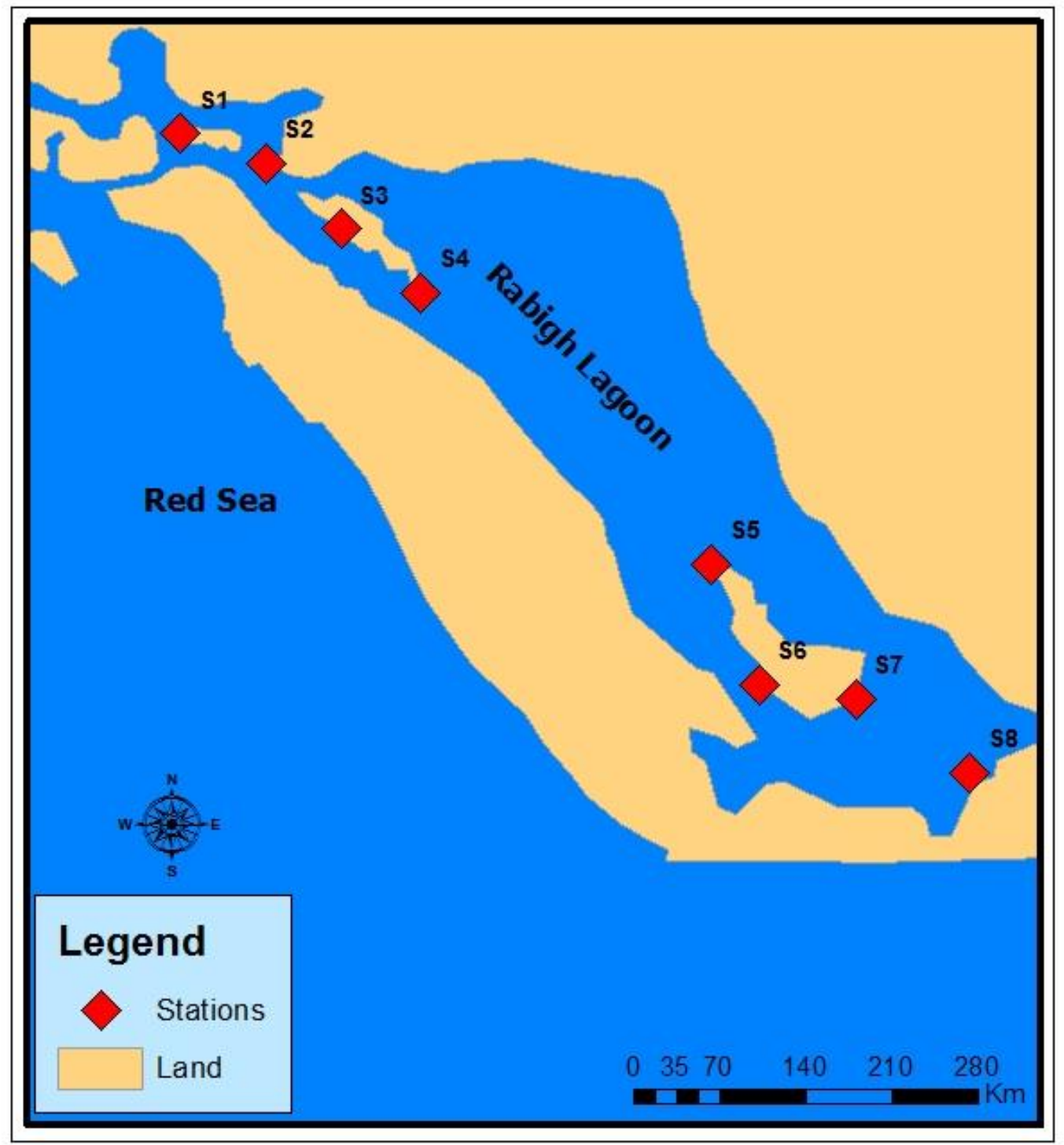

Figure 1. Map of Rabigh lagoon indicating the eight (8) sampling stations.

\subsection{Sample Preparation for Metal Analysis}

In the laboratory, samples of seagrass were washed again with deionized water and checked again for the presence of coarse materials, dead grasses, and epiphytes, which were removed if found. The seagrass was separated into the root, rhizome, and leaf. Samples of seawater were filtered using a filter paper $(2.0 \mu \mathrm{m})$ while a sieve of $2.0 \mathrm{~mm}$ mesh size was used to sieve sediment samples. Both sediment and $C$. serrulata samples from each site were pooled together to normalize the spatial effect of variability within a particular sampling site. Sediment samples were freeze dried at $-20^{\circ} \mathrm{C}$ and C. serrulata samples were oven-dried for $48 \mathrm{~h}$ at $70{ }^{\circ} \mathrm{C}$ to a constant weight, ground into a fine powder using pestle and mortar, and sieved using $63 \mu \mathrm{m}$ mesh size sieve. Sediment and seagrass samples were then stored in zip-lock bags until analysis. Homogenized samples of sediment and C. serrulata compartments in triplicate were digested using concentrated 4:1 $\mathrm{HNO}_{3} / \mathrm{HClO}_{4}$ in a microwave oven (Milestone Ethos 1600 ) at $105^{\circ} \mathrm{C}$ for $2 \mathrm{~h}[9,11]$. 


\subsection{Heavy Metal Analysis}

The digested sediment, seagrass (root, rhizome, and leaf), and seawater samples were analysed to determine concentrations of $\mathrm{Fe}, \mathrm{Mn}, \mathrm{Cu}, \mathrm{Zn}, \mathrm{Cd}, \mathrm{Cr}, \mathrm{Pb}$ and $\mathrm{Ni}$ using inductively coupled plasma mass spectrometry (ICP-MS: Thermo iCAP Qc ICP-MS; Thermo Fischer Scientific, Massachusetts, USA).

Periodic evaluation of the instruments against the low-level standards was conducted once every four samples and recalibrated whenever there were signs of drift or after every 10 samples. The blanks were run concurrently and analytical grade reagents (Merck, Darmstadt, Germany) and matrix modifiers (ammonium phosphate monobasic, Palladium and magnesium nitrate; Perkin Elmer, Massachusetts, USA) were used. The analysis of samples was conducted after about 10-fold dilution using a solution of internal standard, and the precision of the method was verified as described in standard reference material; CRM 279: Ulva lactuca [20].

\subsection{Antioxidant Enzymes Analysis}

Seagrass samples for antioxidant enzymes analysis were washed with deionized water and homogenized by crushing in mortar and pestle, which is ice-cold to maintain the activities of the enzymes, using $0.01(\mathrm{M})$ chilled phosphate buffer and $\mathrm{pH}$ 7. The homogenized samples were centrifuged at 14,000 rpm for $25 \mathrm{~min}[11,18]$. The supernatant was used for the measurement of antioxidant enzyme activities using a spectrophotometer (LT-291 Single Beam UV-VIS).

\subsubsection{Assay of Catalase (CAT) Activity}

Activities of catalase (CAT) in the leaves of $C$. serrulata were determined at $230 \mathrm{~nm}$ using a spectrophotometer by measuring the decrease in absorbance for $2 \mathrm{~min}$. The reaction mixture was made to contain the initial $0.01 \mathrm{M}$ phosphate buffer, $30 \mathrm{mM}$ hydrogen peroxide and $1 \mathrm{~mL}$ of twice diluted enzyme extract. The solution was centrifuged at $5000 \mathrm{rpm}$ for $10 \mathrm{~min}$. Enzyme activity was measured in units/min/mg protein. $1 \mathrm{IU}$ = change in absorbance/min/extinction coefficient (0.021) [21].

\subsubsection{Assay of Glutathione S-Transferase (GST) Activity}

The reaction mixture containing $1 \mathrm{mM}$ 1-chloro 2,4-dinitrobenzene (CDNB), $0.1 \mathrm{M}$ potassium phosphate buffer $\mathrm{pH}$ 6.5, $1 \mathrm{mM}-40 \mathrm{mM} \mathrm{GSH}, 100 \mu \mathrm{L}$ of seagrass tissue extracts in a total volume of $1 \mathrm{~mL}$ was used for the assay [22]. The activity of GST was estimated following the production of GS-DNB (GS-Dinitrobenzene) conjugate by measuring the change in absorbance at $340 \mathrm{~nm}$ for $5 \mathrm{~min}$ at $25^{\circ} \mathrm{C}$ in a UV-visible spectrophotometer.

\subsubsection{Assay of Superoxide Dismutase (SOD) Activity}

A total of $100 \mathrm{mg}$ of $C$. serrulata leaves were homogenised after addition of $500 \mu \mathrm{L}$ of the buffer $\left(40 \mathrm{mM} \mathrm{K}_{2} \mathrm{HPO}_{4}, \mathrm{pH} 7.4\right), 1 \mathrm{mM}$ EDTA, $5 \%(w / v)$ and polyvinylpyrrolidone (molecular weight $=40,000)$. The homogenised leaf samples were centrifuged at 12,000 rpm for $20 \mathrm{~min}$ and the resulting supernatants were used to assay SOD activity, using a spectrophotometer by estimating the absorbance at $450 \mathrm{~nm}$ after $20 \mathrm{~min}$ and at $37^{\circ} \mathrm{C}$ [23]. However, prior to assay of SOD activities spectrophotometrically, $10 \mu \mathrm{L}$ of the supernatant was measured and added to a mixture of $0.1 \mathrm{mM}$ xanthine, $6.25 \mathrm{nM}$ xanthine oxidase, $50 \mathrm{mM} \mathrm{K}_{2} \mathrm{HPO}_{4}$, $\mathrm{pH} 7.8,0.1 \mathrm{mM}$ EDTA, $0.025 \%(w / v)$ Triton X-100, $0.1 \mathrm{mM}$ 2-(4-iodophenyl)-3-(4-nitrophenyl)-5-(2,4-disulfophenyl)-2H-tetrazolium (WST-1). Before the determination of protein concentrations in the plant extract, bovine serum albumen was utilised as the standard. One unit of enzyme activity was equal to the concentration of enzyme required to stop chromogen production by $50 \%$ in one minute under the assay conditions, and specific activity was expressed as units/mg protein. 


\subsubsection{Assay of Acetylcholinesterase (AChE) Activity}

C. serrulata tissues were homogenized in $0.1 \mathrm{M}$ phosphate buffer, $\mathrm{pH} 7.5$, centrifuged at $14,000 \mathrm{rpm}$ for $5 \mathrm{~min}$. AChE activity was determined using the supernatants and a Sigma MK113 AChE Assay Kit (Sigma Aldrich, UK). AChE activity assay using the kit was conducted as described by the manufacturer and was used as a protocol. Samples prepared initially were diluted 40 -fold in assay buffer. The supernatant was utilized after homogenization and centrifuging. ELISA plate reader was used with the kit for AChE assay at $412 \mathrm{~nm}$.

\subsection{Data Analysis}

The Kruskal-Wallis H-test was used to determine significant variations or likely relationship between (i) heavy metals in sediment, water, and seagrasses (ii) heavy metals concentrations across the stations. Spearman correlation coefficient was used to determine the relationships between concentrations of heavy metals and activities of antioxidants. Multivariate factor analysis was used to determine the influence of heavy metals on antioxidative feedback and source and migration of heavy metals. Cluster analysis was used to determine the relationship between the stations in terms of heavy metals concentrations.

The bioconcentration factor $(\mathrm{BCF})$ was computed as:

$$
\mathrm{BCF}=\frac{C_{\text {leaf }}}{C_{\text {sediment }}}
$$

where $C_{\text {leaf }}$ is the concentration of a given metal in leaf in $\mathrm{mg} / \mathrm{kg}$ dry weight, and $\mathrm{C}_{\text {sediment }}$ is the concentration of a given metal in sediment in $\mathrm{mg} / \mathrm{kg}$ dry weight.

BCF defines the effectiveness of $C$. serrulata to bioaccumulate heavy metals in its tissue by taking them up from the sediment [24].

Data analysis was conducted using IBM SPSS v.22.0 and Minitab v.17.0 Statistics Software Package.

\section{Results}

Results revealed that the bioconcentration factors $(\mathrm{BCF})$ were less than $1(\mathrm{BCF}<1)$ for $\mathrm{Fe}, \mathrm{Mn}, \mathrm{Cu}$, $\mathrm{Zn}, \mathrm{Cd}, \mathrm{Cr}, \mathrm{Pb}$ and $\mathrm{Ni}$ (Table 1). Cr recorded the highest value of bioconcentration factor $(\mathrm{BCF}=0.43)$. For the concentrations of heavy metal in seagrass compartment, there was a significant decrease displaying different patterns as root $>$ leaf $>$ rhizome for Fe and $\mathrm{Mn}$, leaf $>$ root $>$ rhizome for $\mathrm{Cu}, \mathrm{Zn}, \mathrm{Pb}$ and $\mathrm{Ni}$, and root $>$ rhizome $>$ leaf for $\mathrm{Cd}$ and $\mathrm{Cr}$. Significant variation $(p<0.05)$ was recorded for heavy metals in sediment, water, and seagrass compartments with sediment displaying high concentrations for all the heavy metals determined in this study. Using sediment quality guidelines (SQGs) [25] to make comparisons with concentrations of metals in sediment and effect range low concentrations (interpreting monitoring concentrations for their toxicity effect or ecological risk) revealed that $\mathrm{Cu}$, $\mathrm{Zn}, \mathrm{Cd}, \mathrm{Pb}$, and $\mathrm{Ni}$ concentrations were above ER-L values and $\mathrm{Cr}$ concentration was below ER-L values. In contrast, concentrations in seawater for all the heavy metals were above the estimate average element concentrations in seawater ECS [26].

Analysis of variance (ANOVA) at $p<0.05$ revealed significant variation in heavy metal concentrations across the eight stations selected in Rabigh lagoon during the study, with station S8 recording the highest concentrations in sediment and leaves of $C$. serrulata (Figure 2). However, the similarity of the stations in terms of heavy metal concentrations was revealed using cluster analysis (Figure 3). The amalgamation steps for the cluster analysis revealed seven similarity levels, with the most significant at 99.82 being the highest value (Table 2). At 99.82 similarity level and distance of 0.003685 , the dendrogram revealed five new cluster formations. Cluster 1 (S1 and S2), cluster 2 (S3 and S6), cluster 3 (S7 and S8), cluster 4 (S4) and cluster 5 (S5). 
Table 1. Heavy metal concentrations in C. serrulata compartments $(\mathrm{mg} / \mathrm{kg})$, seawater $\left(\mu \mathrm{g} \mathrm{L} \mathrm{L}^{-1}\right)$ and sediments $(\mathrm{mg} / \mathrm{kg})$, and bioconcentration factors along Rabigh lagoon.

\begin{tabular}{cccccccccc}
\hline & & $\mathbf{F e}$ & $\mathbf{M n}$ & $\mathbf{C u}$ & $\mathbf{Z n}$ & $\mathbf{C d}$ & $\mathbf{C r}$ & $\mathbf{P b}$ & $\mathbf{N i}$ \\
\hline Leaf & Mean \pm SE & $43.23 \pm 3.88$ & $60.94 \pm 2.82$ & $26.82 \pm 2.01$ & $59.38 \pm 4.22$ & $3.23 \pm 0.57$ & $7.24 \pm 1.34$ & $17.96 \pm 1.98$ & $11.75 \pm 1.05$ \\
Rhizome & Mean \pm SE & $39.76 \pm 2.88$ & $57.49 \pm 3.32$ & $19.77 \pm 1.89$ & $48.64 \pm 3.65$ & $3.30 \pm 0.23$ & $7.95 \pm 1.06$ & $11.99 \pm 1.34$ & $9.33 \pm 1.26$ \\
Roots & Mean \pm SE & $46.56 \pm 3.51$ & $64.38 \pm 3.01$ & $21.88 \pm 2.65$ & $51.74 \pm 5.64$ & $4.03 \pm 0.21$ & $8.04 \pm 1.02$ & $14.28 \pm 1.38$ & $10.22 \pm 1.01$ \\
Seawater & Mean \pm SE & $3.99 \pm 0.49$ & $5.76 \pm 0.53$ & $40.08 \pm 3.40$ & $32.93 \pm 2.12$ & $3.38 \pm 0.06$ & $10.62 \pm 0.53$ & $9.72 \pm 1.92$ & $16.10 \pm 1.43$ \\
Sediment & Mean \pm SE & $1595.50 \pm 176.11$ & $847.79 \pm 125.68$ & $68.88 \pm 5.48$ & $166.47 \pm 12.79$ & $12.38 \pm 1.86$ & $16.89 \pm 1.54$ & $113.44 \pm 4.84$ & $56.52 \pm 6.04$ \\
& ECS & 1.1 & 0.42 & 0.31 & 0.3 & 0.048 & 0.19 & 0.13 & 0.37 \\
BCF & ER-L & & & 34 & 150 & 1.2 & 81 & 46.7 & 20.9 \\
F value & CL/CS & 0.02 & 0.07 & 0.29 & 0.29 & 0.26 & 0.43 & 0.11 & 0.17 \\
$p$ value & & 78.547 & 3.552 & 54.116 & 49.911 & 17.462 & 19.700 & 328.392 & 47.348 \\
\hline
\end{tabular}

ECS: Estimated average element concentrations in seawater $\left(\mu \mathrm{g} \mathrm{L}^{-1}\right)$. ER-L: Effects Range Low guideline values (mg/kg). a After Richir et al. (2013). ${ }^{\mathrm{b}}$ After Long et al. (1995). CL = Concentrations of a given metal in leaf in $\mathrm{mg} / \mathrm{kg}$ dry weight. CS = Concentrations of a given metal in sediment in $\mathrm{mg} / \mathrm{kg}$ dry weight.
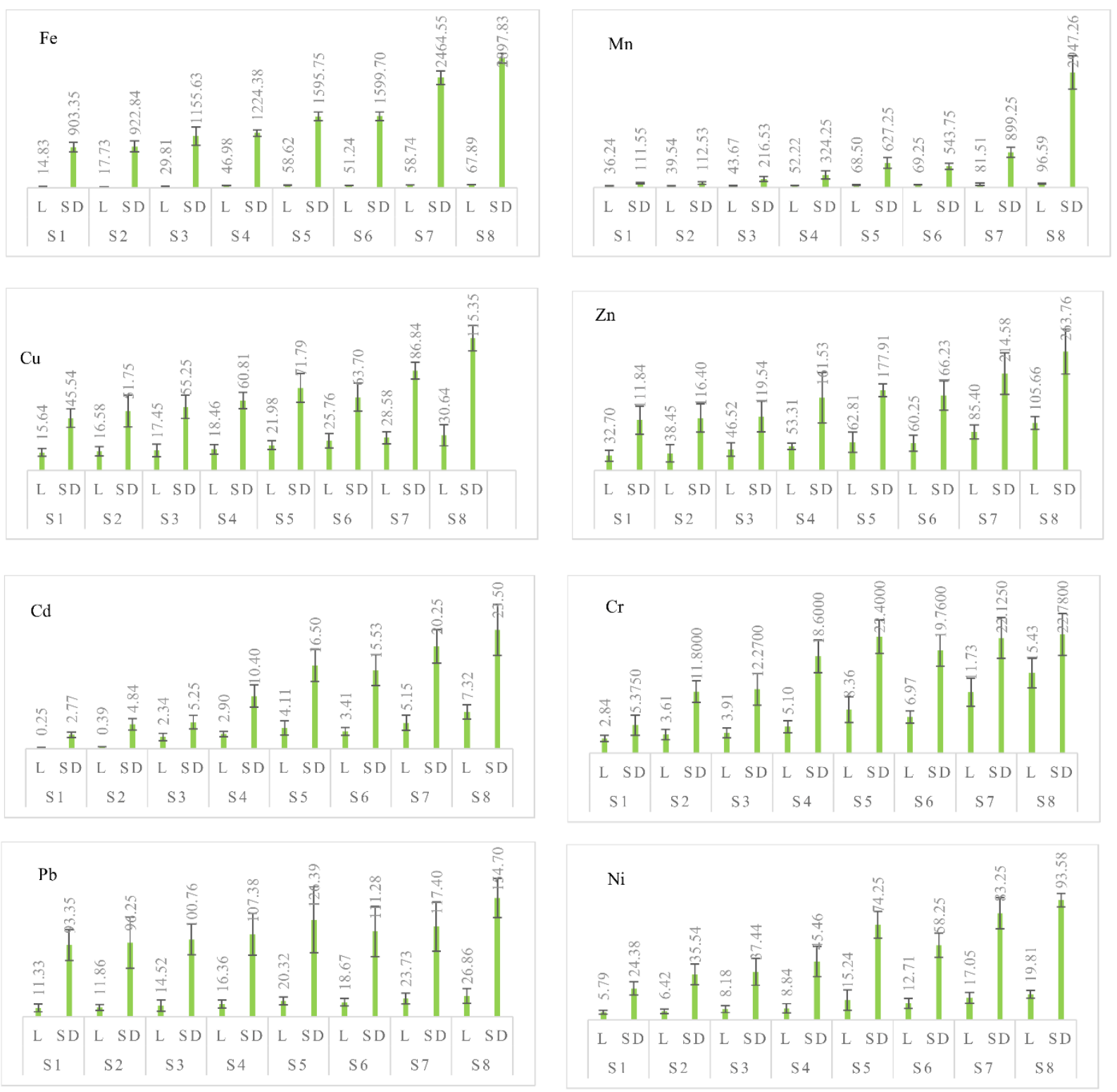

Figure 2. Variation in heavy metals concentration in sediment and seagrass C. serrulata across the stations ( $\mathrm{S}=$ station, $\mathrm{L}=$ leaf, $\mathrm{SD}=$ sediment). 


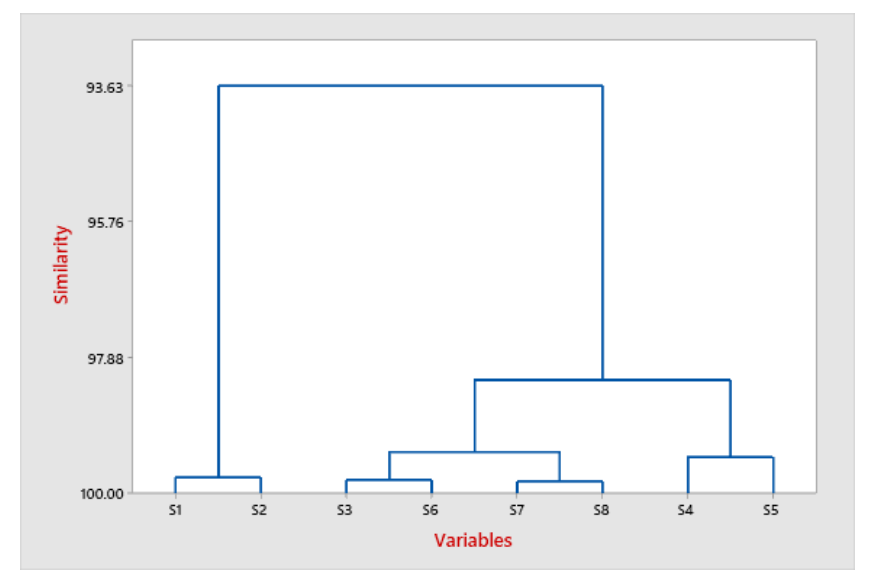

Figure 3. Cluster analysis dendrogram base on heavy metals concentration in seagrass C. serrulata ( $\mathrm{S}=$ station).

Table 2. Amalgamation steps for cluster analysis based on heavy metal concentrations across stations at Rabigh lagoon.

\begin{tabular}{cccccc}
\hline Step & $\begin{array}{c}\text { Number of } \\
\text { Clusters }\end{array}$ & $\begin{array}{c}\text { Similarity } \\
\text { Level }\end{array}$ & Distance Level & New Cluster & $\begin{array}{c}\text { No. of Observation in } \\
\text { the New Cluster }\end{array}$ \\
\hline 1 & 7 & 99.82 & 0.003685 & 5 & 2 \\
2 & 6 & 99.79 & 0.00418 & 3 & 2 \\
3 & 5 & 99.76 & 0.004888 & 1 & 2 \\
4 & 4 & 99.44 & 0.011222 & 4 & 4 \\
5 & 3 & 99.36 & 0.012887 & 3 & 6 \\
6 & 2 & 98.23 & 0.035314 & 3 & 8 \\
7 & 1 & 93.63 & 0.127323 & 1 & 2 \\
\hline
\end{tabular}

In this study, antioxidative feedback was determined by evaluations of four antioxidant enzymes activities. These antioxidants are important biomarkers of oxidative stress in organisms expose to environmental pollutants either in-situ or ex-situ. Changes in plant physiology can be monitored in a scenario where the organism is under stress as a result of persistent environmental pollutants in an environment, leading to the production of reactive oxygen species such as $\mathrm{H}_{2} \mathrm{O}_{2}, \mathrm{OH}, \mathrm{O}_{2}$ in a biosystem $[2,4,19]$. The antioxidants are catalase (CAT), superoxide dismutase (SOD), glutathione S-transferase (GST) and acetylcholinesterase (AChE).

The activities of these antioxidants are presented in Figure 4. Significant variations $(p<0.05)$ in CAT, SOD, GST, and AChE were established across the eight stations where samples were collected, with peak activities of the antioxidants at station S8 corresponding to the peak heavy metal concentration in sediment and C. serrulata. Antioxidants activities in C. serrulata range from CAT: $6.67-89.69 \mathrm{U} \mathrm{g}^{-1}$ protein, SOD: 2.70-20.57 $\mathrm{U} \mathrm{g}^{-1}$ protein, GST: $23.29-72.70$ and AChE: $11.89-142.75 \mathrm{U} \mathrm{g}^{-1}$ protein. Pearson correlation coefficient $(p<0.01)$ showed a significant positive correlation between the heavy metals and between the four antioxidant enzymes and heavy metal concentrations in C. serrulata (Table 3). 

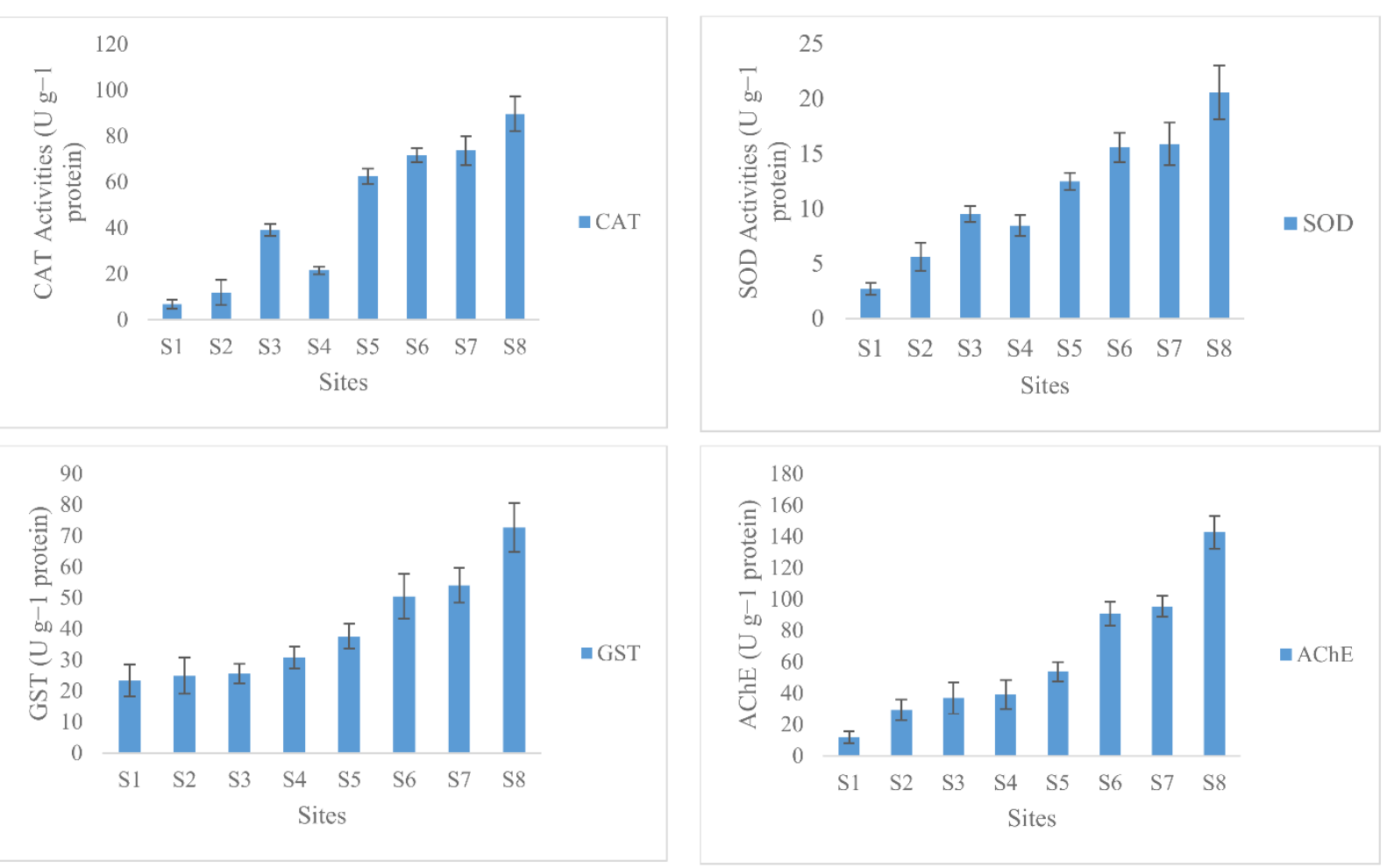

Figure 4. Antioxidant enzymes activities in seagrass C. serrulata across the stations. CAT = catalase, $\mathrm{GST}=$ glutathione S-transferase, $\mathrm{SOD}=$ superoxide dismutase, $\mathrm{AChE}=$ acetylcholinesterase.

Table 3. Pearson correlation matrix for heavy metal concentration and antioxidant activities in C. serrulata.

\begin{tabular}{|c|c|c|c|c|c|c|c|c|c|c|c|c|}
\hline & $\mathrm{Fe}$ & Mn & $\mathrm{Cu}$ & $\mathrm{Zn}$ & $\mathrm{Cd}$ & $\mathrm{Cr}$ & $\mathbf{P b}$ & $\mathrm{Ni}$ & SOD & CAT & AChE & GST \\
\hline $\mathrm{Fe}$ & 1 & & & & & & & & & & & \\
\hline $\mathrm{Mn}$ & $0.904^{* *}$ & 1 & & & & & & & & & & \\
\hline $\mathrm{Cu}$ & $0.866^{* *}$ & $0.957^{* *}$ & 1 & & & & & & & & & \\
\hline $\mathrm{Zn}$ & $0.878^{* *}$ & $0.956^{* *}$ & $0.923 * *$ & 1 & & & & & & & & \\
\hline $\mathrm{Cd}$ & $0.931 * *$ & $0.935^{* *}$ & $0.917^{* *}$ & $0.972 * *$ & 1 & & & & & & & \\
\hline $\mathrm{Cr}$ & $0.864^{* *}$ & $0.958^{* *}$ & $0.944^{* *}$ & $0.978^{* *}$ & $0.955^{* *}$ & 1 & & & & & & \\
\hline $\mathrm{Pb}$ & $0.939 * *$ & $0.971^{* *}$ & $0.953 * *$ & $0.968^{* *}$ & $0.983^{* *}$ & $0.977^{* *}$ & 1 & & & & & \\
\hline $\mathrm{Ni}$ & $0.924^{* *}$ & $0.965^{* *}$ & $0.947^{* *}$ & $0.946^{* *}$ & $0.962 * *$ & $0.971^{* *}$ & $0.988^{* *}$ & 1 & & & & \\
\hline SOD & $0.904 * *$ & $0.948^{* *}$ & $0.956^{* *}$ & 0.936 ** & $0.943 * *$ & $0.914^{* *}$ & $0.948^{* *}$ & 0.940 ** & 1 & & & \\
\hline CAT & $0.890^{* *}$ & $0.920^{* *}$ & $0.940^{* *}$ & $0.883^{* *}$ & $0.913^{* *}$ & $0.884^{* *}$ & $0.929^{* *}$ & $0.945^{* *}$ & $0.976^{* *}$ & 1 & & \\
\hline AChE & $0.831^{* *}$ & $0.941 * *$ & $0.971^{* *}$ & $0.953^{* *}$ & $0.919^{* *}$ & 0.940 ** & $0.929^{* *}$ & $0.914^{* *}$ & $0.966^{* *}$ & $0.920^{* *}$ & 1 & \\
\hline GST & $0.837^{* *}$ & $0.952 * *$ & $0.977^{* *}$ & $0.955^{* *}$ & $0.917^{* *}$ & $0.954^{* *}$ & $0.937^{* *}$ & $0.925^{* *}$ & $0.946^{* *}$ & $0.908^{* *}$ & $0.992 * *$ & 1 \\
\hline
\end{tabular}

Note: ** Correlation is significant at the 0.01 level (2-tailed), CAT = catalase, GST = glutathione S-transferase, SOD = superoxide dismutase, $\mathrm{AChE}=$ acetylcholinesterase.

Factor analysis performed to determine the interrelationship between the antioxidants and heavy metals concentration in C. serrulata, in terms of source input, migration of heavy metals, and their influence on the rise in antioxidants activities, is presented in Table 4 and Figure 5. The extent to which data were spread was determined by the value of eigenvalue, and the reason for consideration of high eigenvalue as the principal component. Our results revealed that factors 1,2 and 3 accounted for $33.6 \%$, $32.7 \%$, and $31.8 \%$ of the total variation, respectively. Factor 1 has a variance of 4.0285 , dominating factors 2 and 3 with a variance of 3.9206 and 3.8213, respectively. The loadings for heavy metals and antioxidants in factor 1 have moderate positive loadings ( $>0.50)$ of $\mathrm{Mn}, \mathrm{Cd}, \mathrm{Pb}, \mathrm{Ni}, \mathrm{AChE}$, and GST while strong positive loadings $(>0.70)$ were displayed for $\mathrm{Zn}$ and $\mathrm{Cr}$. For factor 2, moderate positive loadings ( $>0.50)$ for $\mathrm{Mn}, \mathrm{Zn}, \mathrm{Cd}, \mathrm{Pb}, \mathrm{Ni}, \mathrm{SOD}$, and CAT and strong positive loading ( $>0.70)$ of Fe was recorded. Factor 3 with less variation recorded moderate positive loadings ( $>0.50)$ of $\mathrm{Mn}, \mathrm{Cu}, \mathrm{SOD}$, 
AChE and GST, and strong positive loading $(>0.70)$ of CAT. However, the results of these loadings are translated in factor analysis biplot (Figure 5) revealing the relationships between the parameters with the measurement of their vectors corresponding to the positive loadings. Grouping the antioxidants and metals in such a way give a better explanation as to the influence of heavy metals on the increasing activities of the four antioxidants.

Table 4. Factor analysis loadings for heavy metal concentrations in C. serrulata and antioxidants activities.

\begin{tabular}{ccccc}
\hline Variable & Factor $\mathbf{1}$ & Factor $\mathbf{2}$ & Factor $\mathbf{3}$ & Communality \\
\hline $\mathrm{Fe}$ & 0.394 & 0.814 & 0.395 & 0.974 \\
$\mathrm{Mn}$ & 0.6 & 0.555 & 0.541 & 0.961 \\
$\mathrm{Cu}$ & 0.551 & 0.463 & 0.676 & 0.975 \\
$\mathrm{Zn}$ & 0.716 & 0.51 & 0.458 & 0.983 \\
$\mathrm{Cd}$ & 0.602 & 0.651 & 0.433 & 0.974 \\
$\mathrm{Cr}$ & 0.731 & 0.499 & 0.452 & 0.989 \\
$\mathrm{~Pb}$ & 0.606 & 0.64 & 0.466 & 0.995 \\
$\mathrm{Ni}$ & 0.567 & 0.644 & 0.489 & 0.974 \\
$\mathrm{SOD}$ & 0.452 & 0.563 & 0.681 & 0.985 \\
$\mathrm{CAT}$ & 0.349 & 0.608 & 0.701 & 0.982 \\
$\mathrm{AChE}$ & 0.607 & 0.381 & 0.691 & 0.99 \\
$\mathrm{GST}$ & 0.645 & 0.383 & 0.652 & 0.989 \\
Variance & 4.0285 & 3.9206 & 3.8213 & 11.7704 \\
\% Var & 0.336 & 0.327 & 0.318 & 0.981 \\
\hline
\end{tabular}

Strong loading values ( $>0.7)$; moderate loading values $(>0.5)$.

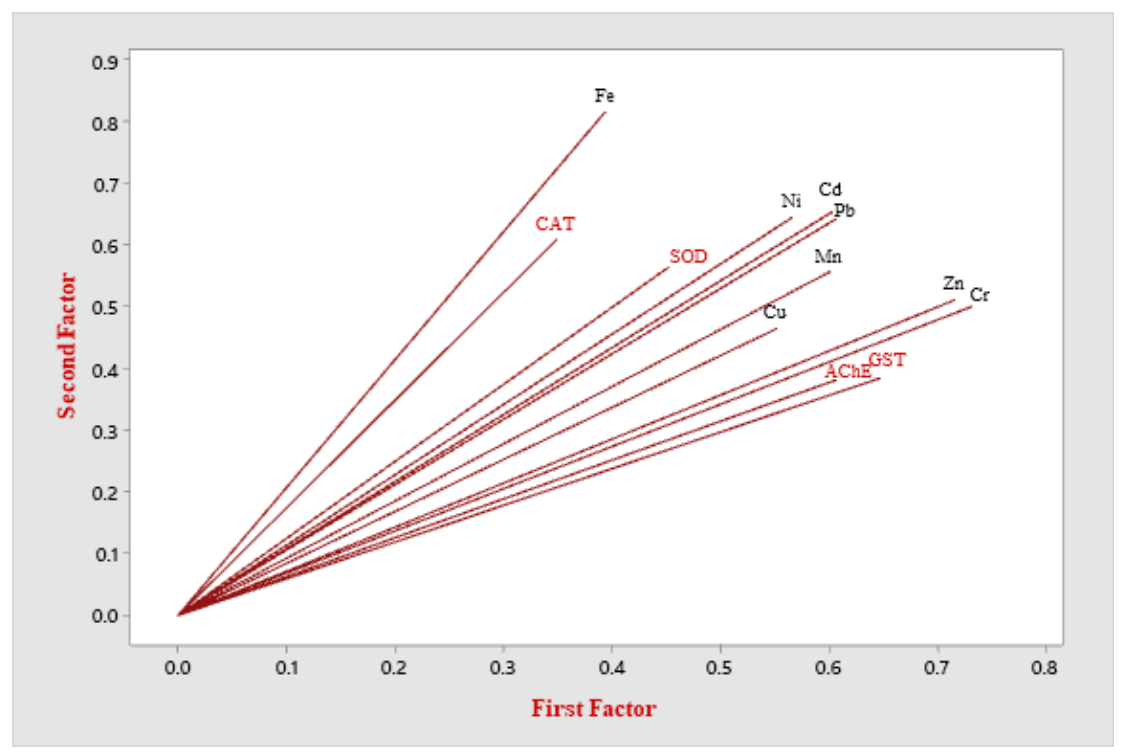

Figure 5. Factor analysis biplot for heavy metal concentrations and antioxidants. CAT = catalase, $\mathrm{GST}=$ glutathione $\mathrm{S}$-transferase, $\mathrm{SOD}=$ superoxide dismutase, $\mathrm{AChE}=$ acetylcholinesterase .

\section{Discussion}

The results from this study put forward that $C$. serrulata is an excluder and accumulator $[6,11]$ of $\mathrm{Fe}, \mathrm{Mn}, \mathrm{Cu}, \mathrm{Zn}, \mathrm{Cd}, \mathrm{Cr}, \mathrm{Pb}$, and $\mathrm{Ni}$, and has on average the ability to translocate heavy metals from sediments to the seagrass compartments. In summary, bioaccumulation or translocation of heavy metals from benthic sediment to above-ground seagrass compartments are not a function of only morphological or structural and physiological variations in seagrass compartments, but also the element involved [13]. Translocation of metals may be because of interactions between several environmental factors such as the physicochemical properties of an environment and metal speciation $[1,10,27]$. 
This might be the key reason for variation in BCF values of heavy metals determined in this study and the highest value of $\mathrm{BCF}$ recorded for $\mathrm{Cr}$. Our results are in line with the findings of Bonanno and Raccuia [1] where they compare accumulation of heavy metals in three species of seagrasses and reported variations in BCF values ranging between 0 and 3 for different elements determined.

Concerning the concentrations of heavy metals in seagrass compartments, the different patterns or trends established suggested the individual roles of the compartments in the translocation of metals. However, the root is seen to play a more prominent role as bioaccumulator compartment for $\mathrm{Cd}, \mathrm{Cr}, \mathrm{Fe}$, and Mn using the trends with root $>$ rhizome $>$ leaf and root $>$ leaf $>$ rhizome, while leaf plays a more prominent role as bioaccumulator compartment for $\mathrm{Cu}, \mathrm{Zn}, \mathrm{Pb}$, and $\mathrm{Ni}$ in the trend with leaf $>$ root $>$ rhizome. The mechanism of exclusion and detoxification may be the key reason for more efficient heavy metal sink in root and leaves compartments [1].

The accumulation of high concentrations of metals in tissues that are not involved in photosynthesis, for example, roots, and detoxification strategy in non-permanent tissues such as leaves are the main tolerance strategy $[6,28]$. This may be the reason for the high concentrations of metals in root and leaves compartments of $C$. serrulata [6,29]. Heavy metals such as $\mathrm{Fe}, \mathrm{Cu}$, and $\mathrm{Mn}$ at the tolerable range are essential for growth but become toxic if the concentrations rise above tolerable limits. In contrast, metals such as $\mathrm{Pb}, \mathrm{Cd}$, and $\mathrm{Cr}$ are toxic to plants even at low concentrations [30]. Exclusion and detoxification as a strategy of tolerance have been reported from previous studies to have a link with translocation of noxious metals from roots to leaves which may speed up the loss of metals due to recurring regeneration of $C$. serrulata leaves $[9,10]$.

The significant variation and higher concentrations of heavy metals in sediment compared to seawater and C. serrulata compartments could be due to the presence of allochthonous metal pollutants link to anthropogenic activities at the catchment and atmospheric deposition of some the metals $[2,4,12]$. This can also be a reflection of aquatic benthic sediment as sinks for heavy metals in polluted aquatic ecosystems $[7,31]$. The high concentrations of these metals in sediment is also revealed in the relationship between the metal concentrations with ER-L and ECS values [26] with all the metal concentrations except $\mathrm{Cr}$ exceeding ER-L, and all exceeding ECS. This implies these metals possess a high ecological risk $[25,32]$ to the Rabigh lagoon.

Heavy metal distribution variability across the sampling stations and high concentrations at station $\mathrm{S} 8$ can be due to irregularity in depositional [33] and input of surface runoff from the Rabigh city into the lagoon. Most of the surface runoff gets into the lagoon through station S8, and coagulation and sedimentation are evidenced here due to intermixing of freshwater and the seawater, and also inefficient circulation and exchange between the lagoon and the Red Sea [11]. The presence of autochthonous metals because of geomorphological factors, the process of natural weathering, and several allochthonous sources such as anthropogenic activities may play a key role in variations in metal concentrations in the stations both for sediments and leaves of $C$. serulata $[18,33,34]$. The different groups of clusters for stations formed based on heavy metals concentrations are a result of the close relationships of stations in the same cluster. The characteristics of these stations relative to autochthonous and allochthonous sources of metals and other physiological features could be some key reasons for groups formed in the different clusters [11,35].

Antioxidative feedback due to heavy metal bioaccumulation in C. serrulata at the cellular level causes the production of reactive oxygen species (ROS) which may lead to oxidative stress or cellular damage. To prevent oxidative stress, the biological system produces antioxidant enzymes such as CAT, SOD, GST, and AChE, among others, to scavenge ROS like an antibody reaction to infections by pathogenic microorganisms [2,18]. Significant variations across the stations with higher antioxidant enzyme activities in station $\mathrm{S} 8$ corresponds to the trend for concentrations of heavy metals. This can be due to increased ROS production with increase heavy metal concentrations and forms the basis for significant positive correlation $(p<0.01)$ between the four antioxidants and the heavy metals determined in this study. Similar findings were reported in several works of literature $[15,18,19]$. 
However, AChE stands out as the first antioxidant in line of defence presenting higher activities to scavenge ROS than the other antioxidants. This may be due to the sensitivity of AChE to the heavy metals and direct effects of heavy metals on AChE coding genes [17]. However, the decrease in antioxidants activities in some stations like stations S1 and S2 corresponds to a decrease in heavy metal concentrations. The key reason for the decrease in antioxidants activities could be due to decreased ROS production and displacement of vital metal ions from biomolecules by heavy metals [36]. Our observations were consistent with Lin et al. [17] where they describe activities of antioxidants as biomarkers in seagrass exposed to copper, lead, and cadmium.

The use of factor analysis in this study revealed the sources and migration of heavy metals and their influence on antioxidant activities. For factor 1, moderate positive loadings of $\mathrm{Mn}, \mathrm{Cd}, \mathrm{Pb}, \mathrm{Ni}$, $\mathrm{AChE}$, and GST and strong positive loadings of $\mathrm{Zn}$ and $\mathrm{Cr}$ recorded revealed a significant influence of $\mathrm{Mn}, \mathrm{Cd}, \mathrm{Pb}$, and $\mathrm{Ni}$ on the increasing activities of AChE and GST. Also, the close relationship between $\mathrm{Zn}$ and $\mathrm{Cr}$ may be as a result of the two metals having the same sources. This also implies that $\mathrm{Mn}$, $\mathrm{Cd}, \mathrm{Pb}, \mathrm{Ni}, \mathrm{Zn}$, and $\mathrm{Cr}$ could be from urban and industrial sources or effluents that end up into the lagoon through surface runoff [37]. The same reason is attributed to loadings displayed for factor 2 and 3 with less variance when compared to factor 1 . However, factors 2 and 3 revealed moderate positive loadings for $\mathrm{Mn}, \mathrm{Zn}, \mathrm{Cd}, \mathrm{Pb}, \mathrm{Ni}, \mathrm{SOD}$, and $\mathrm{CAT}$ and moderate positive loadings of $\mathrm{Mn}, \mathrm{Cu}$, $\mathrm{SOD}, \mathrm{AChE}$, and GST, respectively. This suggests that $\mathrm{Mn}, \mathrm{Zn}, \mathrm{Cd}, \mathrm{Pb}$, and Ni influence an increase in activities of SOD and CAT while Mn and $\mathrm{Cu}$ influence an increase in SOD, AChE, and GST activities; $\mathrm{Mn}, \mathrm{Zn}, \mathrm{Cd}, \mathrm{Pb}, \mathrm{Ni}$, and $\mathrm{Cu}$ could be products of urban and industrial waste from the catchments of Rabigh lagoon $[2,38,39]$.

\section{Conclusions}

This study revealed that $C$. serrulata is a good accumulator and excluder of $\mathrm{Fe}, \mathrm{Mn}, \mathrm{Cu}, \mathrm{Zn}$, $\mathrm{Cd}, \mathrm{Cr}, \mathrm{Pb}$, and $\mathrm{Ni}$. However, it has a different capacity to bioaccumulate or translocate each heavy metal as shown in the variation in bioconcentration factor. Root plays a more prominent role as a bioaccumulator compartment for $\mathrm{Cd}, \mathrm{Cr}, \mathrm{Fe}$, and $\mathrm{Mn}$, and leaf for $\mathrm{Cu}, \mathrm{Zn}, \mathrm{Pb}$, and $\mathrm{Ni}$, revealing the mechanism of exclusion and detoxification as a key reason for more efficient heavy metal sink in these two compartments. Concentrations of heavy metals in sediment and seawater samples were above ER-L and ECS except Cr in sediment and were a reflection of benthic sediment as a sink for heavy metals in a polluted environment. Concentrations of heavy metals were particularly high at station S8 and corresponded to high antioxidative feedback at the same station.

Significant variations existed in CAT, SOD, GST, and AChE activities across the stations and were influenced by concentrations of heavy metals. $\mathrm{Mn}, \mathrm{Cd}, \mathrm{Pb}$, and $\mathrm{Ni}$ influence increased activities of $\mathrm{AChE}$ and GST while $\mathrm{Mn}, \mathrm{Zn}, \mathrm{Cd}, \mathrm{Pb}$, Ni, influence increased activities of SOD and CAT. In contrast, at the lowest variation, $\mathrm{Mn}$ and $\mathrm{Cu}$ influence an increase in SOD, AChE and GST activities.

Our result established the bioaccumulation efficiency of $C$. serrulat $a$ and the need for the potential use of antioxidative feedback as biomarkers of metal pollutants through assays of CAT, SOD, GST, and AChE. Thus, the need for promotion of a biomonitoring network across the marine environment using seagrasses and antioxidant enzymes as biomarkers of oxidative stress caused by environmental pollutants.

Author Contributions: M.O.A., and A.B.A. conceived the idea and performed the laboratory analysis. All of the authors contributed to give the manuscript its present shape. All authors have read and agreed to the published version of the manuscript.

Funding: This research was funded by the Deanship of Scientific Research (DSR), King Abdulaziz University, Jeddah, under grant number D-491-130-1441. The authors, therefore, gratefully acknowledge DSR technical and financial support.

Acknowledgments: The authors acknowledge the Deanship of Scientific Research (DSR), King Abdulaziz University, Jeddah for their technical and financial support.

Conflicts of Interest: The authors declare there is no conflict of interest. 


\section{References}

1. Bonanno, G.; Raccuia, S.A. Comparative assessment of trace element accumulation and bioindication in seagrasses Posidonia oceanica, Cymodocea nodosa and Halophila stipulacea. Mar. Pollut. Bull. 2018, 131, $260-266$. [CrossRef] [PubMed]

2. Aljahdali, M.O.; Alhassan, A.B. Metallic Pollution and the Use of Antioxidant Enzymes as Biomarkers in Bellamya unicolor (Olivier, 1804) (Gastropoda: Bellamyinae). Water 2020, 12, 202. [CrossRef]

3. Rainbow, P.S. Trace metal bioaccumulation: Models, metabolic availability and toxicity. Environ. Int. 2007, 33, 576-582. [CrossRef]

4. Aljahdali, M.O; Alhassan, A.B. Spatial Variation of Metallic Contamination and Its Ecological Risk in Sediment and Freshwater Mollusk: Melanoides tuberculata (Müller, 1774) (Gastropoda: Thiaridae). Water 2020, 12, 206. [CrossRef]

5. Youssef, M.; El-Sorogy, A. Environmental assessment of heavy metal contamination in bottom sediments of Al-Kharrar lagoon, Rabigh, Red Sea, Saudi Arabia. Arab. J. Geosci. 2016, 9, 474. [CrossRef]

6. Almahasheer, H. High levels of heavy metals in Western Arabian Gulf mangrove soils. Mol. Biol. Rep. 2019, 46, 1585-1592. [CrossRef]

7. Alhassan, A.; Balarabe, M.; Gadzama, I. Assessment of some heavy metals in macobenthic invertebrate and water samples collected from Kubanni reservoir Zaria, Nigeria. FUW Trends Sci. Technol. J. 2016, 1, 55-60.

8. Bonanno, G.; Orlando-Bonaca, M. Chemical elements in Mediterranean macroalgae. A review. Ecotoxicol. Environ. Saf. 2018, 148, 44-71. [CrossRef]

9. Malea, P.; Kevrekidis, T. Trace element (Al, As, B, Ba, Cr, Mo, Ni, Se, Sr, Tl, U and V) distribution and seasonality in compartments of the seagrass Cymodocea nodosa. Sci. Total Environ. 2013, 463, 611-623. [CrossRef]

10. Bonanno, G.; Cirelli, G.L. Comparative analysis of element concentrations and translocation in three wetland congener plants: Typha domingensis, Typha latifolia and Typha angustifolia. Ecotoxicol. Environ. Saf. 2017, 143, 92-101. [CrossRef]

11. Aljahdali, M.O.; Alhassan, A.B. Ecological risk assessment of heavy metal contamination in mangrove habitats, using biochemical markers and pollution indices: A case study of Avicennia marina L. in the Rabigh lagoon, Red Sea. Saudi J. Biol. Sci. 2020, 27, 1174-1184. [CrossRef]

12. Farias, D.; Hurd, C.; Eriksen, R.; Macleod, C. Macrophytes as bioindicators of heavy metal pollution in estuarine and coastal environments. Mar. Pollut. Bull. 2018, 128, 175-184. [CrossRef] [PubMed]

13. Malea, P.; Mylona, Z.; Kevrekidis, T. Trace elements in the seagrass Posidonia oceanica: Compartmentation and relationships with seawater and sediment concentrations. Sci. Total Environ. 2019, 686, 63-74. [CrossRef] [PubMed]

14. Sureda, A.; Box, A.; Terrados, J.; Deudero, S.; Pons, A. Antioxidant response of the seagrass Posidonia oceanica when epiphytized by the invasive macroalgae Lophocladia lallemandii. Mar. Environ. Res. 2008, 66, 359-363. [CrossRef] [PubMed]

15. Ferreira, C.P.; Lima, D.; Paiva, R.; Vilke, J.M.; Mattos, J.J.; Almeida, E.A.; Grott, S.C.; Alves, T.C.; Corrêa, J.N.; Jorge, M.B. Metal bioaccumulation, oxidative stress and antioxidant responses in oysters Crassostrea gasar transplanted to an estuary in southern Brazil. Sci. Total Environ. 2019, 685, 332-344. [CrossRef]

16. Bhat, A.H.; Dar, K.B.; Anees, S.; Zargar, M.A.; Masood, A.; Sofi, M.A.; Ganie, S.A. Oxidative stress, mitochondrial dysfunction and neurodegenerative diseases; a mechanistic insight. Biomed. Pharmacother. 2015, 74, 101-110. [CrossRef]

17. Lin, H.; Sun, T.; Zhou, Y.; Zhang, X. Anti-oxidative feedback and biomarkers in the intertidal seagrass Zostera japonica induced by exposure to copper, lead and cadmium. Mar. Pollut. Bull. 2016, 109, 325-333. [CrossRef]

18. Bakshi, M.; Ghosh, S.; Chakraborty, D.; Hazra, S.; Chaudhuri, P. Assessment of potentially toxic metal (PTM) pollution in mangrove habitats using biochemical markers: A case study on Avicennia officinalis L. in and around Sundarban, India. Mar. Pollut. Bull. 2018, 133, 157-172. [CrossRef]

19. Asaeda, T.; Barnuevo, A. Oxidative stress as an indicator of niche-width preference of mangrove Rhizophora stylosa. For. Ecol. Manag. 2019, 432, 73-82. [CrossRef]

20. Roca, G.; Romero, J.; Farina, S.; Martínez-Crego, B.; Alcoverro, T. Using seagrasses to identify local and large-scale trends of metals in the Mediterranean Sea. Mar. Pollut. Bull. 2017, 123, 83-91. [CrossRef]

21. Chance, B.; Maehly, A.C. Assay of Catalase and Peroxidase. Methods Enzymol. 1955, 2, 764-775. 
22. Habig, W.H.; Pabst, M.J.; Jakoby, W.B. Glutathione S-transferases the first enzymatic step in mercapturic acid formation. J. Biol. Chem. 1974, 249, 7130-7139. [PubMed]

23. Keyster, M.; Klein, A.; Ludidi, N. Caspase-like enzymatic activity and the ascorbate-glutathione cycle participate in salt stress tolerance of maize conferred by exogenously applied nitric oxide. Plant Signal. Behav. 2012, 7, 349-360. [CrossRef]

24. Agency, U.E.P. Framework for metals risk assessment. Ecotoxicol. Environ. Saf. 2007, 68, 145-227.

25. Long, E.R.; Macdonald, D.D.; Smith, S.L.; Calder, F.D. Incidence of adverse biological effects within ranges of chemical concentrations in marine and estuarine sediments. Environ. Manag. 1995, 19, 81-97. [CrossRef]

26. Richir, J.; Luy, N.; Lepoint, G.; Rozet, E.; Azcarate, A.A.; Gobert, S. Experimental in situ exposure of the seagrass Posidonia oceanica (L.) Delile to 15 trace elements. Aquat. Toxicol. 2013, 140, 157-173. [CrossRef]

27. Yang, J.; Ye, Z. Metal accumulation and tolerance in wetland plants. Front. Biol. China 2009, 4, $282-288$. [CrossRef]

28. Dahmani-Muller, H.; Van Oort, F.; Gelie, B.; Balabane, M. Strategies of heavy metal uptake by three plant species growing near a metal smelter. Environ. Pollut. 2000, 109, 231-238. [CrossRef]

29. Baker, A.J. Accumulators and excluders-strategies in the response of plants to heavy metals. J. Plant Nutr. 1981, 3, 643-654. [CrossRef]

30. Shahid, M.; Ferrand, E.; Schreck, E.; Dumat, C. Behavior and impact of zirconium in the soil-plant system: Plant uptake and phytotoxicity. In Reviews of Environmental Contamination and Toxicology; Springer: Berlin/Heidelberg, Germany, 2013; Volume 221, pp. 107-127.

31. Thanh-Nho, N.; Strady, E.; Nhu-Trang, T.T.; David, F.; Marchand, C. Trace metals partitioning between particulate and dissolved phases along a tropical mangrove estuary (Can Gio, Vietnam). Chemosphere 2018, 196, 311-322. [CrossRef]

32. Long, E.; MacDonald, D. Recommended uses of empirically derived, sediment quality guidelines for marine and estuarine ecosystems. Hum. Ecol. Risk Assess. 1998, 4, 1019-1039. [CrossRef]

33. Ghosh, S.; Ram, S.S.; Bakshi, M.; Chakraborty, A.; Sudarshan, M.; Chaudhuri, P. Vertical and horizontal variation of elemental contamination in sediments of Hooghly Estuary, India. Mar. Pollut. Bull. 2016, 109, 539-549. [CrossRef]

34. Agah, H.; Bastami, K.D.; Fumani, N.S. Ecological risk, source and preliminary assessment of metals in the surface sediments of Chabahar Bay, Oman Sea. Mar. Pollut. Bull. 2016, 107, 383-388. [CrossRef] [PubMed]

35. Rahman, M.S.; Hossain, M.B.; Babu, S.O.F.; Rahman, M.; Ahmed, A.S.; Jolly, Y.; Choudhury, T.; Begum, B.; Kabir, J.; Akter, S. Source of metal contamination in sediment, their ecological risk, and phytoremediation ability of the studied mangrove plants in ship breaking area, Bangladesh. Mar. Pollut. Bull. 2019, 141, 137-146. [CrossRef] [PubMed]

36. Schützendübel, A.; Polle, A. Plant responses to abiotic stresses: Heavy metal-induced oxidative stress and protection by mycorrhization. J. Exp. Bot. 2002, 53, 1351-1365. [CrossRef]

37. Suresh, G.; Ramasamy, V.; Meenakshisundaram, V.; Venkatachalapathy, R.; Ponnusamy, V. Influence of mineralogical and heavy metal composition on natural radionuclide concentrations in the river sediments. Appl. Radiat. Isot. 2011, 69, 1466-1474. [CrossRef]

38. Mohiuddin, K.; Otomo, K.; Ogawa, Y.; Shikazono, N. Seasonal and spatial distribution of trace elements in the water and sediments of the Tsurumi River in Japan. Environ. Monit. Assess. 2012, 184, 265-279. [CrossRef]

39. Alhassan, A.B.; Abidemi, A.; Gadzama, I.M.K.; Sha'aba, R.I.; Wada, Y.A.; Kelassanthodi, R. Distribution and diversity of freshwater snails of public health importance in Kubanni reservoir and weir/sediment trap, Zaria, Nigeria. J. Environ. Occup. Sci. 2020, 10. [CrossRef]

(C) 2020 by the authors. Licensee MDPI, Basel, Switzerland. This article is an open access article distributed under the terms and conditions of the Creative Commons Attribution (CC BY) license (http://creativecommons.org/licenses/by/4.0/). 